\title{
Creating Religious Identities: Buddhist Monuments in Colonial and Post-colonial India
}

\author{
Transforming Cultures eJournal, \\ Vol. 3 No 2, November 2008 \\ http://epress.lib.uts.edu.au/journals/TfC
}

\author{
Himanshu Prabha Ray ${ }^{1}$ \\ Centre for Historical Studies \\ Jawaharlal Nehru University, New Delhi
}

\begin{abstract}
This paper draws on my work on the maritime history of early South and Southeast Asia and the use of sea-lanes of the Indian Ocean by pilgrims for visits to sites associated with the life of the Buddha. A second perspective is provided by the rediscovery of Buddhism in Europe coinciding with the development of new disciplines, including archaeology. These disciplines were introduced into India with the government-sponsored Archaeological Survey of India, founded in 1871. Alexander Cunningham, the first Director-General, brought Buddhism to the forefront and established its study as a separate subdiscipline. This had far-reaching implications for the demarcation and archaeological investigation of many of the monuments linked to Buddhism, especially Bodh Gaya and Sanchi. This paper addresses the issue of the manifestation of a Buddhist identity in colonial India. It is often suggested that this identity owed its origins to the formation of the Mahabodhi Society and the emergence of nationalism in Sri Lanka. This paper examines political developments in India in the context of the Navayana or the Neo-Buddhist path, forged by B.R. Ambedkar on the $2500^{\text {th }}$ anniversary of Buddha's parinirvana, or demise, in 1956. To what extent did this newly formed identity become interlinked with the identification and control of archaeological sites in India and their redefinition? How did the renegotiation of Buddhist identity affect India's relationship with Thailand?
\end{abstract}

"We have embarked on this pilgrimage to see the signs of the history of India's entry into the universal."

Thus wrote Rabindranath Tagore as he embarked on a sea voyage on 15 July 1927 on the French ship Amboise to Java and other countries of Southeast Asia. ${ }^{2}$ It was an

\footnotetext{
${ }^{1}$ Himanshu Prabha Ray is Associate Professor in the Centre for Historical Studies, Jawaharlal Nehru University, New Delhi. She researches seafaring in the Indian Ocean and the history of archaeology and its influence religion. She is currently working on digital mapping of ancient Indian religious sites.

${ }^{2}$ Sugata Bose, A Hundred Horizons, New Delhi: Permanent Black, 2006: 245.
} 
intellectual pilgrimage and Tagore's only motive, Bose argues, was "to collect source materials there for the history of India and to establish a permanent arrangement for research in this field." ${ }^{3}$ Bose stresses Tagore's attempts at highlighting the theme of cultural exchange between the two regions and the creativity of the Javanese and other peoples of Southeast Asia in negotiating with Indian cultural forms and products. Tagore was also aware of regional differences in historical developments within India and the fact that relations of the Srivijaya kingdom $\left(6^{\text {th }}\right.$ to $14^{\text {th }}$ centuries AD) were largely with the Palas of eastern India. ${ }^{4}$

Only a few years earlier, in 1912, Radha Kumud Mookerji had published his doctoral thesis completed at Calcutta University under the title Indian Shipping: A History of the Sea-borne Trade and Maritime Activity of the Indians from the Earliest Times. The frontispiece of the book showed a relief from Borobudur with a sailing ship under the caption 'Indian Adventurers sailing out to colonize Java'. Period of Hindu Imperialism in Northern India', dealt with the maritime activity of the Bengalis based on a collection of poems of more than fifty authors describing sea voyages titled Padma Purana or Manasamangala.

In the same manner that Shakespeare's Antonio had "an argosy bound for Tripoli, another for the Indies, a third for Mexico, and a fourth for England" is our Indian S'rimanta represented to possess merchantmen trading to the Coromandel coast, to Ceylon, to Malacca, Java and China. ${ }^{6}$

How does one reconcile these contrasting views that emerged in the early $20^{\text {th }}$ century: one, focussed on Hindu imperialism and the colonisation of parts of Southeast Asia; the other, emphasising universal history and India's cultural capital?

This paper is an attempt at addressing the construction of India's past under colonial rule, especially in terms of its linkages with Southeast Asia both at the theoretical level of 'Indianisation' as also at the micro-level of the history of one complex, viz. that of Bodh Gaya. The basic premise that this paper questions is the extent to which the

\footnotetext{
${ }^{3}$ Bose, 2006: 245.

${ }^{4}$ Bose 2006: 259.

${ }^{5}$ Radha Kumud Mookerji, Indian Shipping: A History of the Sea-borne Trade and Maritime Activity of the Indians from the Earliest Times, London: Longmans Green and Company, 1912.

${ }^{6}$ Mookerji 1912: 158.
} 
construction of knowledge in the $20^{\text {th }}$ century can be slotted into binary opposites of 'colonialism' and 'nationalism,' the latter, it is argued by some historians writing within the socio-economic framework in the post-Independence period, being not only a reaction to the former, but also containing the seeds of the 'communalisation' of history. The same trend is continued in recent writings, which suggest that new forms of knowledge introduced in the colonial period, such as archaeology and art history, were scientific and based on elaborate documentation, and that nationalist writings, such as those of R. K. Mookerji or Ananda K. Coomaraswamy, which had recourse to traditional accounts and Sanskrit texts, were essentially attempts at harking back to a glorious past. ${ }^{7}$

In this paper, the attempt is to "uncover the genealogies, which have constructed and (re)produced these texts,, 8 - the texts in this case being histories of nation states, as well as heritage sites that invoke and recreate collective memory. This raises the issue of the relationship between material culture and texts, or somewhat simplistically between archaeology and history. Linked to this are the histories of archaeology in Asia and the extent to which the imposition of new disciplines during colonial rule and the identification and creation of heritage sites has a bearing on the study of the past. Histories written over the last five decades in different countries of Asia have primarily dealt with the ancient period of the present nation states and the discussion has largely centred on present national boundaries and local identities versus external influences. Perhaps it is time to move beyond the paradigm of the nation state in researching the history of Asia since in the earlier periods these frontiers had little meaning. It is crucial to address the 'coloniality of power' and the rigid hierarchies imposed between different knowledge systems in the colonial period and the extent to which they remain unquestioned and continue to be reproduced in post-colonial writings. "Our question would then be: Do we live in a world where the old epistemological hierarchies made

\footnotetext{
7 "The issue of territoriality acquired a new edge as Indian art history spilled over its national boundaries to tell the story of the spread of Indian art and religion across China, Japan and Southeast Asia." GuhaThakurta proposes this served as "a major sop to national pride" and reinforced the idea of India as the source of Asian art, Tapati Guha-Thakurta, Monuments, Objects, Histories, New Delhi: Permanent Black, 2004: 187.

${ }^{8}$ Henk Schulte Nordholt, De-colonising Indonesian historiography, Working Paper in Contemporary Asian Studies, no. 6, 2004, Center for East and South-East Asian Studies, University of Lund, Sweden: 1.
} 
rigid by modern colonialism have disappeared, or on the contrary, are we witnessing a postmodern reorganization of coloniality?",

\section{I 'Indianisation' - the framing of the debate}

It is not often appreciated that archaeology developed as a discipline over the last three to four hundred years in Europe and North America and was transposed to Asia with the introduction of colonial rule. There is no uniformity in the introduction of archaeology and the uses to which it was put in different parts of Asia. In this section I shall focus on the Indian subcontinent and Southeast Asia. It may be stressed that while in early colonial writings the monuments and histories of Asia are said to have been 'discovered', clearly this was an overstatement of the case, as these monuments and histories had never been lost to the local communities. It was just that European administrators and military officials understood the past in somewhat different terms. Secondly, colonial interest in most cases was with documentation and conservation, rather than with religious practice. Documentation started in the $19^{\text {th }}$ century, while conservation became a priority somewhat later, in the early part of the $20^{\text {th }}$ century, especially in India. No doubt, both these activities altered notions of the past in Asia and changed the terms of reference irretrievably. The attempt here is both to trace these changes and to comprehend the extent to which these were implicated not only in the writing of the histories of nation states, but also in governance and the establishment of institutions of learning.

In many ways, the histories of archaeological development in South and Southeast Asia overlapped, both through the personnel involved and also because large parts of island Southeast Asia were under British rule. A common concern of early authors was to publicise Britain's newly acquired territories and to add first-hand knowledge to scientific writings on recent 'rediscovery'. ${ }^{10}$ It is significant that the academic discourse often involved theories of race and language, which were firmly entrenched in Europe at this time. It is evident that, already in the $19^{\text {th }}$ century, British political interests in Burma, Indonesia and other regions of Southeast Asia had resulted in the concept of

\footnotetext{
${ }^{9}$ Santiago Castro Gómez, 'The Missing Chapter of Empire: Post-modern Reorganization of Coloniality and post-Fordist Capitalism', Cultural Studies, volume 21, numbers 2-3, March-May 2007: 428.

${ }^{10}$ Mary Catherine Quilty, Textual Empires: A Reading of Early British Histories of Southeast Asia, Monash Asia Institute, Clayton, 1998: 3.
} 
"Further India", as John Marshall, the Director-General of the Archaeological Survey of India, termed Southeast Asia in 1902. ${ }^{11}$ The academic discourse included discussions on topics such as language, architecture and religious structures in Southeast Asia, in addition to the more direct ASI intervention in conservation policies in Burma.

The French and the British continued to be engaged in the geopolitics of control of cultural knowledge in South and Southeast Asia, but more sinister were attempts at creating reified Hindu and Buddhist spaces in the archaeology of Asia. In the early 1900s, Curzon ordered a number of photographs of Angkor Wat from Saigon, while Louis Finot, the first Director of EFEO, stressed the need to catch up with the progress made by the British. "Such scholastic ambitions correlated with nostalgia for France's eighteenth century loss of its Indian empire to Britain, as reflected in popular French depictions of Cambodia and its monuments as 'France's' India". ${ }^{12}$ In the $19^{\text {th }}$ century, the Khmers were Theravada Buddhists, but revered Angkor as a symbol of their religion or sāsanā, which was devoid of the denominational divide between Hinduism and Buddhism.

The presence of Buddhist statues and the practice of Buddhist worship at Angkor presented unwelcome challenges to colonial desires to compartmentalise Cambodia both vertically, through time, and horizontally, through the categorisation of religion. On site, the Hindu framing of Cambodia encouraged Angkor's new guardians not only to relocate members of the Cambodian monkhood or sangha, but also to remove Buddhist statues that had been erected in positions of central prominence and sacred significance during the temple's centuries-long conversion to a site of Buddhist worship. During the following decade, colonial attempts to re-Indianise Angkor would see the quarantining of scores of such Buddhist icons in a designated space, which became known as Mille Bouddha (thousand Buddha) gallery. Those monks, who had been the chief curators of the temple complex long before the EFEO was founded, were also cleared off the land in 1909 as their presence in front of the temple was considered an eyesore. ${ }^{13}$

In a strange twist of irony, French writings on the archaeology of Southeast Asia were taken up by Greater India polemicists in their nationalist fervour as they wrote of cultural conquest. Many of the influential thinkers of the society, such as P.C. Bagchi

${ }^{11}$ Archaeological Survey of India - Annual Report 1902-03: 2

${ }^{12}$ Penny Edwards, 'Relocating the interlocutor: Taw Sein Ko (1864-1930) and the itinerancy of knowledge in British Burma', South East Asia Research, volume 12, number 3, 2004: 277-335, p. 290.

${ }^{13}$ Penny Edwards, 'Taj Angkor: Enshrining L'Inde in le Cambodge' in Kathryn Robson and Jennifer Lee (ed.) France and "Indochina”: Cultural Representations, Lexington Books, Oxford, 2005: 13-28, p. 17. 
(1898-1956) and Kalidas Nag (1891-1966), had studied in Paris with celebrated Indologists, Sylvain Lévi (1863-1935) and Jean Przyluski (1885-1944). Not only did the Director of EFEO, George Coedès, praise these attempts at rediscovery of the Indian heritage of colonization, but these interactions between Indian and French scholars of Further India and Greater India continued well into the 1950 s. $^{14}$

The 'Indianisation' model has continued to affect archaeologists working in South and Southeast Asia over the last five decades, though it is seldom that the genealogy of the process itself has been scrutinised. The archaeological work is often seen as establishing that the region had achieved social complexity by the early centuries and that Indian influence was selectively assimilated into the pre-existing cultural base. The focus continues on identifying the 'indigenous cultural matrix' and its unilinear progression towards urbanisation and statehood. The achievements of the past in terms of "the age of the state, the longevity of settlement sites, and the inventiveness of early bronze or ceramic technologies have been of vital importance to contemporary national communities, an importance that is translated into issues for today's scholars."15

The situation is not very different in South Asia. It is unfortunate that in the postIndependence period in India, with the shift from the writing of political history to socio-economic history, not only were many of the so-called 'nationalist' writings rejected outright, but more significantly religion came to be studied in relation to modes of production in Indian history. Historians associated Buddhism and Jainism with the growth of trade resulting from the development of an agrarian surplus around the middle of the first millennium B.C. This was followed by a decline of trade, rise of feudal tendencies in Indian society and the decay of towns from 300 A.D. onwards. ${ }^{16}$ Buddhism is said to have declined and the post $4^{\text {th }}$ century period is seen as marking a transitional phase between the sacrificial Vedic religion and the emergence of Puranic

${ }^{14}$ Susan Bayly, 'French Anthropology and the Durkheimians in Colonial Indo China', Modern Asian Studies, volume 34, no. 3, July 2000: 602.

${ }^{15}$ Craig J. Reynolds, Seditious Histories: Contesting Thai and Southeast Asian Pasts, University of Washington Press, Seattle and London, 2006: 5.

16 "De-urbanisation was therefore a feature of the first or classic phase of feudalism marked by a subject peasantry and a dominant class of landlords in conditions of languishing trade and predominantly agrarian economy. It inaugurated an era of closed economy in which the needs of landed intermediaries were met locally without the effective intervention of traders whose functions were reduced to the minimum" (R. S. Sharma, Urban Decay in India, New Delhi, 1987: 184). 
worship characterised by the migration of brahmanas from the towns and the development of tîrthas or sacred spots. ${ }^{17}$ It is suggested that at numerous feudal centres temples were constructed in permanent material such as stone for the first time in the $5^{\text {th }}$ century A.D. ${ }^{18}$ Though not all historians accept the feudalism model and the fragmentation of society that it suggests, yet the migration of brahmanas and acculturation of tribal communities has generally been supported. Chattopadhyaya, for example, associated this movement with the formation of regional and sub-regional kingdoms and their requirement for legitimisation. ${ }^{19}$ In effect then, historians have explained the origins of the temple in terms of the requirements of the local political elite or landed intermediaries for legitimisation of their newly emerging status in a period of urban decay, decline of trade and agrarian expansion. There is unanimity also in the association with migrations of brahmanas and their role as priests in consolidating the new cults, frequently described as of Puranic affiliation. ${ }^{20}$

In contrast to the conventional linear development from Buddhist caitya to Hindu temple, archaeological data establishes that both the Buddhist caitya and the Hindu temple were contemporaneous in the $3^{\text {rd }}-1^{\text {st }}$ centuries B.C. and shared sacred space with a diverse range of domestic, local and regional cults. ${ }^{21}$ Nor was the religious identity of a centre restricted to one or the other religion. Multiple affiliation was the norm rather than the exception, as exemplified by the caves at Ellora. The earliest cave excavation at the site began in the late $6^{\text {th }}$ century and was dedicated to Siva, followed by Buddhist,

\footnotetext{
${ }^{17}$ R. N. Nandi, Social Roots of Religion in Ancient India, Calcutta, 1986.

18 "Several temples were built outside the main Gupta - Vakataka domain, e.g. in Gujarat, Bengal, Assam and Punjab. Building of temples away from the main centres and land grants to brahmanas in uncleared territories led to dissemination of knowledge of agriculture, calendar and technology and boosted agrarian expansion. It accelerated the Sanskritisation process in tribal areas and remote villages. The Ramayana and Mahabharata appeared for the first time in temple art at Nachna, Deogadh, Gaddhwa, Paunar and other sites", (D. Desai, "Social Dimensions of Art in Early India", Proceedings of the Indian History Congress, Gorakhpur, 1989-90: 31).

19 "The rapid growth in the number and networks of temple centers, whose origins certainly date to preGupta times, become understandable when we begin to appreciate how closely they were linked, as were gifts and land grants to Brahmins (brahmadeyas and agraharas) with the formation of subregional and regional kingdoms and their legitimation, consolidation of their resource bases, and the forging of linkages for social integration across communities." (B. D. Chattopadyaya, "Historiography, History and Religious Centers" in Vishakha N. Desai and Darielle Mason (eds) Gods, Guardians and Lovers, New York, 1993: 42).

${ }^{20}$ Vijay Nath, Puranas and Acculturation - A Historico-Anthropological Perspective, New Delhi: Munshiram Manoharlal, 2001.

${ }^{21}$ Himanshu Prabha Ray, 'The Archaeology of Sacred Space: an Introduction', Himanshu Prabha Ray and Carla Sinopoli (eds) Archaeology as History in Early South Asia, Indian Council for Historical Research and Aryan Books International, New Delhi, 2004.
} 
Brahmanical and Jaina caves over the next several centuries. ${ }^{22}$ Another example of this is the sacred landscape of Bodh Gaya, which was venerated both by the Buddhists and the Hindus.

A second realisation evident from the archaeological record is the close association between religious architecture, both Buddhist and Hindu, and the community. An early Buddhist monastic site that provides evidence for embankments and tanks associated with agriculture is Sanchi, located on Sanchi hill, an outcrop of Vindhyan sandstone in central India, 6 kilometres from the ancient town of Vidisha. ${ }^{23}$ The earliest monument at the site is an inscribed stone pillar of Asoka dated to the $3^{\text {rd }}$ century B.C. and an apsidal shrine, while it is the imposing stupa Number 1 that occupies the central point on the hill. The entire region is studded with nearly 50 stupas, monasteries and temples, which continued well into the $12^{\text {th }}$ century A.D. and also include the four monastic sites of Sonari, Satdhara, Andher and Morel-Khhurd. It needs to be stressed that Sanchi forms part of a continuous chain of 27 hills consisting of 700 painted rock shelters littered with prehistoric and historical sites.

Thus the archaeological record highlights shared spaces, but what is relevant to this discussion is the transformation of these shared spaces in the colonial period and the contestation and control sought over them as religious identities came to be redefined and reconstructed in South Asia in the $19^{\text {th }}$ and $20^{\text {th }}$ centuries. An appropriate example of this process may be seen in the biography of the Mahabodhi temple at Bodh Gaya located on the Phalgu River, a tributary of the Ganga, 182 kilometres south of Patna, the capital of Bihar. The objective is to comprehend the multi-layered narratives of religious architecture and the extent to which these changed over time.

\section{The Making of a Buddhist Identity}

In the second section, we examine the role of Buddhist monuments, especially Bodh Gaya, within the larger context of the creation of cultural and religious identities in South Asia. A distinction is evident between the pre-colonial period, when diverse

${ }^{22}$ G. H. Malandra, 'The Mandala at Ellora/ Ellora in the Mandala', Journal of the International Association of Buddhist Studies, 19,2, 1996: 181-208.

${ }^{23}$ Shaw, 'Ancient Irrigation Works in the Sanchi Area: an archaeological and hydrological investigation', South Asian Studies, volume 17, 2001: 55-68. 
monuments shared sacred space with an array of domestic, local and regional cults, and the colonial phase, which reinforced monotheistic identities.

Colonial intervention not only altered our understanding of the structures from being abodes of god to objects of artistic and aesthetic appreciation, but it also redefined the nature of Indic religions. Colonial understanding of religion as faith followed a Christianized model of religion that strongly emphasized theistic belief, exclusivity and a fundamental dualism between the human world and the transcendent world of the divine. Religion came to be understood in terms of doctrine, which could only be comprehended through texts rather than through practices and rituals. Once we shift the meaning of religion to its pre-Christian etymology, it is understood in terms of performing ancient ritual practices and paying homage to the gods. In keeping with this, I suggest that pan-Indian religious and cultural practices, rituals and imagery formed the substratum of self-perception and cultural identity long before the creation of 'religious' categories by the British in India.

Traditional wisdom maintains that Buddhism declined in India in the $7^{\text {th }}$ century A.D. Contrary to this assumption there is evidence to suggest that religious communication continued across the Bay of Bengal, as evident from gifts of Sanskrit Mahayana and Tantric texts from Bengal to monasteries in Myanmar. The Gadaladeniya rock inscription of A.D. 1344 from Sri Lanka records the restoration of a two-storey image house at Dhanyakataka in Andhra by a sthavira named Dharmakirti. ${ }^{24}$ The pillar inscription of A.D. 1182, during the rule of Keta II, refers to the presence of a Saiva temple of Amaresvara and adjacent to it a very lofty caitya of lord Buddha. ${ }^{25}$ Another epigraph, dated to A.D. 1234, mentions a grant to the Buddha 'who is pleased to reside at Sri Dhanyakataka'. It is then evident that far from declining, the Buddhist religious networks were vibrant and dynamic. How did these networks change with the formation of the Mahabodhi Society and the emergence of nationalism in Sri Lanka? To what extent did this newly formed identity become interlinked with the identification and control of archaeological sites in India and their redefinition?

\footnotetext{
${ }^{24}$ Epigraphia Zeylanica 4: 90.

${ }^{25}$ Epigraphia Indica, 6, 1900-1901: 146-60.
} 
At one level, the worship of the stupa is a religious duty linked to spiritual emancipation, but one which also places the worshipper within the larger domain of Buddhist religious identity, defined as sasana and extending across Asia, while at the same time relocating the religious monument in the specificity of a regional culture. The sasana permeated ethnic and political boundaries both within the subcontinent and beyond. It provided identity through obligatory pilgrimage and rituals and laid the foundation of an extensive religious and cultural ethos extending across the Indian Ocean. These linkages were often routes of cultural interaction, which in no way diminished the autonomy of the Buddhist Sangha. ${ }^{26}$

It is curious that the Pali Vinaya contains no rules governing the behaviour of monks with regard to stupas, nor does it define the shape and form of the stupa to be worshipped. This absence has generally been taken to mean that the construction and worship of stupas was the concern of laymen and women rather than monks and nuns. Schopen argues against this assumption based on data from inscriptions which refer to donations by Buddhist monks and nuns. ${ }^{27}$ The active participation of Buddhist clergy in the stupa cult and their mobility across Asia is a factor that is seldom taken into account in the study of the religious architecture of Asia. In the next three sections I trace the history of Bodh Gaya and the Buddhist networks starting from the present and working backwards into the ancient period, the objective being to highlight both continuities and changes.

\section{The Present}

In 2002, UNESCO included the Mahabodhi temple complex at Bodh Gaya as a World Heritage site. ${ }^{28}$ It is located on the Phalgu River, a tributary of the Ganga, 182

\footnotetext{
${ }^{26}$ Himanshu Prabha Ray, The Archaeology of Seafaring in Ancient South Asia, Cambridge University Press, 2003: chapter X.

${ }^{27}$ Gregory Schopen, 'The Stupa Cult and the Extant Pali Vinaya' in Bones, Stones and Buddhist Monks, Honolulu: University of Hawaii Press, 1997: 86-98.
}

\section{${ }^{28}$ Justification for Inscription}

Criterion (i) The grand 50m high Mahabodhi Temple of the 5th-6th centuries is of immense importance, being one of the earliest temple constructions existing in the Indian sub-continent. It is one of the few representations of the architectural genius of the Indian people in constructing fully developed brick temples in that era. Criterion (ii) The Mahabodhi Temple, one of the few surviving examples of early brick structures in India, has had significant influence in the development of architecture over the centuries. Criterion (iii) The site of the Mahabodhi Temple provides exceptional records for the events associated with the life of Buddha and subsequent worship, particularly since Emperor Asoka built the

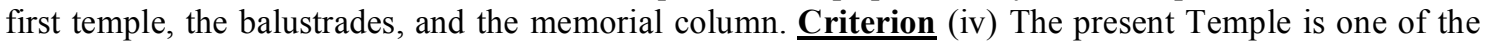


kilometres south of Patna, the capital of Bihar. This decision revolved around two basic issues: one, the fact that the $5^{\text {th }}-6^{\text {th }}$ century Mahabodhi temple is the earliest surviving brick temple in South Asia, and the second, that it marked the spot associated with the life of the Buddha where the Mauryan ruler Asoka constructed the first temple.

Today the area within one kilometre of the Mahabodhi temple is dotted with several monasteries, such as the Indosan Nipponji Japanese Temple, which houses a Buddha image, at least three Tibetan monasteries, and a number of houses of worship maintained by Sri Lankan, Bhutanese, Chinese, Vietnamese and Nepalese monks. A Thai monastery called Wat Thai Buddha-Gaya, which was constructed by the Thai Government at the invitation of the Government of India to celebrate the BuddhaJayanti, was completed in 1966. These monasteries are primarily centres of worship, learning and meditation for both monks and lay people.

This oasis of religious peace lies in Jehanabad district in central Bihar, a stronghold of Marxist-Leninist extremists, and venturing out after dark is dangerous. These obstacles to land and sea travel have, however, been overcome by several Southeast Asian governments in order to make the journey to Bodh Gaya and other sites of pilgrimage safer for their citizens. Thai Airways operates chartered flights from Bangkok to Varanasi and Gaya, 14 kilometres from Bodh Gaya.

It was an easy flight from Bangkok to Varanasi in India, a three and a half hour journey across the Andaman Sea and halfway across the Indian sub-continent. ${ }^{29}$

This contemporary phase in the history of Buddhism in India may perhaps be traced from 1956 onwards when B.R. Ambedkar $(1891$ - 1956) forged the Navayana or NeoBuddhist path on the $2500^{\text {th }}$ anniversary of Buddha's parinirvana. Ambedkar had studied anthropology and law and was a prominent member of the committee that drafted the National Constitution of independent India. This committee also adopted the use of the Sarnath lion capital and its wheel as the symbol of the new Republic. These

earliest and most imposing structures built entirely in brick from the late Gupta period. The sculpted stone balustrades are an outstanding early example of sculptural reliefs in stone. Criterion (v) The Mahabodhi Temple Complex in Bodh Gaya has direct association with the life of the Lord Buddha, being the place where He attained the supreme and perfect insight.

${ }^{29}$ Harold Stephens, 'Flying Visit to the Birthplace of the Lord Buddha,' Bangkok Post, 23 February 2005. 
recommendations have to be viewed in the context of Ambedkar's personal convictions.

On 14 October 1956, Ambedkar held a public conversion or diksa at which he and half a million of his followers left Hinduism and converted to the Neo-Buddhist faith. ${ }^{30} \mathrm{U}$. Chandramani, a Burmese monk, the oldest bhikkhu in India, administered the vows to Ambedkar and others followed him. ${ }^{31}$

Ambedkar's primary focus seems to have been not so much to change the Brahmanical system, but to "use a polemical critique of Brahmanical religio-social dominance, as the foundation upon which to develop an Indic-based alternative to the Brahmanical social order." 32 In the quest for social justice against caste hierarchy in modern India, a new meaning was given to Buddhism, while at the same time drawing on the ancient Theravada Buddhist tradition. ${ }^{33}$ In the creation of this new identity, Ambedkar stressed the differences between Buddhism and Hinduism and gave the former a distinctive character, rejecting in the process the tradition that the Buddha was an incarnation of the Hindu deity Visnu. ${ }^{34}$ It is significant that, while accepting the contribution of Buddhism, S. Radhakrishnan, the President of India did not support this dichotomy between Hinduism and Buddhism. As Radhakrishnan wrote in the Foreword to the volume titled 2500 Years of Buddhism edited by P.V. Bapat on the occasion of the anniversary celebrations: ${ }^{35}$

\footnotetext{
${ }^{30}$ Gary M. Tartakov, 'New Paths to Sanchi' in V. Dehejia, (ed.) Unseen Presence: The Buddha and Sanchi, Marg Publications, 1996: 120.

${ }^{31}$ Gail Omvedt, Buddhism in India: Challenging Brahmanism and Caste, New Delhi: Sage Publications, 2003: 261.

${ }^{32}$ Anne M. Blackburn, 'Kinship and Buddhism: Ambedkar's Vision of a Moral Community', Journal of the International Association of Buddhist Studies, 16:1 (1993): 1-23.

33 'Like the village deity and national deity, there were family deities who were worshipped through the Brahmins. The priests who used to go for worshipping these deities started influencing the affairs of the state through the queens. Asoka, after embracing Buddhism, discontinued this practice and removed the idols of such deities. Asoka said, "As I venerate the Buddha, the Enlightened One, there is no need to worship any other deity". This action of Asoka disturbed the Brahmins very much as it ended their unfair means of livelihood and exploitation. They pledged to take revenge for this loss', (B.R. Ambedkar, On Buddhism, D.C. Ahir, (ed.), Bombay, 1982: 113 as quoted in D.C. Ahir, Asoka the Great, Delhi: B.R. Publishing, 1995: 122). It must be remembered that this book was not completed before he died. Instead the notes written by Ambedkar were edited afterwards (Timothy Fitzgerald, 'Ambedkar, Buddhism and the Concept of Religion' in S. M. Michael, (ed.) Untouchable: Dalits in Modern India, Boulder: Lynne Rienner Publishers, 1999: 64).

${ }^{34}$ Omvedt, 2003: 262.

35 S. Radhakrishnan, Foreword, P.V. Bapat (ed.) 2500 Years of Buddhism, New Delhi: Publications Division, 1956.
} 
The Buddha utilized the Hindu inheritance to correct some of its expressions. He came to fulfil, not to destroy. For us, in this country, the Buddha is an outstanding representative of our religious tradition. He left his footprints on the soil of India and his mark on the soul of the country with its habits and convictions. While the teaching of the Buddha assumed distinctive forms in the other countries of the world in conformity with their own traditions, here, in the home of the Buddha, it has entered into and become an integral part of our culture. The Brahmins and the Sramanahs were treated alike by the Buddha and the two traditions gradually blended. In a sense the Buddha is a maker of modern Hinduism.

It was at this time that the Government of India, under the directive of Prime Minister Jawaharlal Nehru, decided to revitalize Buddhism in India. Thailand was the first country to build a monastery and the temple in Bodh Gaya was constructed under a lease agreement between the governments of India and Thailand.

\section{The Colonial Past}

The $19^{\text {th }}$ century marked a break from the earlier notion of Indian history of the preMuslim period. Sir William Jones and his colleagues, working under the aegis of the Asiatic Society in 1784, had largely concentrated on the Puranas, the epics and the law books to develop a history of the Hindus. In contrast, research by James Prinsep (17991840) and Alexander Cunningham (1814-1893) clearly brought Buddhism to the forefront and established its study as a legitimate branch of historical enquiry in the second quarter of the $19^{\text {th }}$ century. In 1846 Major Markham Kittoe was appointed Archaeological Surveyor to the Government of India and one of the first sites to which he directed his attention was Bodh Gaya. On his death, his papers were dispersed. The sculptures he had collected were sent to the India House Museum and the rest made over to the Museum of the Asiatic Society of Bengal. Bodh Gaya is one of the first sites that General Cunningham visited on being appointed Archaeological Surveyor in 1861 and in 1863 Major Meade dug a few trenches at the site. ${ }^{36}$ Cunningham's primary objective was to identify and locate sacred sites associated with the life of the Buddha.

It is significant that many of Cunningham's formulations, such as his identification of places associated with the life of the Buddha, description of Buddha as a social reformer, the prominent role of the Mauryan ruler Asoka in spreading the faith and the

\footnotetext{
${ }^{36}$ A. Cunningham, Mahabodhi, London: W.H. Allen and Company, 1892: i.
} 
degenerate nature of Buddhism after the $7^{\text {th }}$ century A.D., continue to be repeated in secondary writings. By the $7^{\text {th }}$ century, Cunningham claimed, the Buddhist monks had become an indolent and corrupt body, content to spend their lives in the monotonous routine of monastic life. ${ }^{37}$ Another abiding concern of Cunningham was the biography of the historical Buddha and identification of the scenes of the Buddha's life on the sculpted panels of Bharhut, Sanchi and Bodh Gaya. This $19^{\text {th }}$ century emphasis on the life of the Buddha continues undiminished and has undermined a full appreciation of the richness of Buddhist imagery. ${ }^{38}$

In contrast to Cunningham's oft-repeated conclusions, viz. that Buddhism declined in the $7^{\text {th }}$ century A.D., Sri Lanka is one of the regions that historically maintained close relations with the temple complex at Bodh Gaya. These contacts date from the $1^{\text {st }}$ century B.C., when a pilgrim from Sri Lanka donated a railing around the Bodhi tree at Bodh Gaya, and continue almost into the present. ${ }^{39}$ The religious complex at Bodh Gaya has continued well into the modern period and there is evidence for patronage by the Burmese in the $13^{\text {th }}$ century and records of pilgrims on pavement slabs show that it was under worship in the $14^{\text {th }}$ century.

Myanmar was another region that developed close ties with the sacred centre, which are well documented from the reign of King Aniruddha (1044-77) onwards. It was during the reign of King Aniruddha that the first mission was sent to Bodh Gaya to repair and support the Mahabodhi temple and a record of this is provided by a Mon inscription from Prome. The inscription refers to different kinds of jewels being sent on a ship by Aniruddha's general, Kyanzittha, for building up the temple of Bodh Gaya, which had been destroyed by other kings. The funds were also to be used for supporting the

\footnotetext{
${ }^{37}$ A. Cunningham, The Bhilsa Topes, Varanasi: Indological Book House, 1966: 2.

38 Janice Leoshko, Sacred Traces: British Explorations of Buddhism in South Asia, London: Ashgate, 2003: 18 .

${ }^{39}$ In the $5^{\text {th }}$ century A.D., the sramana Prakhyatakirti of the royal family of Sri Lanka performed acts of worship at the site (D. Mitra, Buddhist Monuments, Calcutta: Sahitya Samsad, 1980: 62). The connection with Sri Lanka continued and donatory inscriptions dated to the $6^{\text {th }}$ century A.D. record gifts by the Sri Lankan monk Mahanaman (A. Cunningham, Mahabodhi or the Great Buddhist Temple under the Bodhi Tree at Buddha-Gaya, London, 1892, reprint Varanasi: Indological Book House: 42-3; 60-2). Around the $12^{\text {th }}$ century, an inscription in the Patna Museum records the installation of an image of Buddha by the Sri Lankan Udayasri. Several $13^{\text {th }}$ century inscriptions survive from Bodh Gaya indicating a special role for Sri Lankan monks; indeed one of these records the donation of a village to the Vajrasana for the upkeep of its monastery and the donation is made into the trust of the Bhiksu Mangalasvamin from Sri Lanka (Janice Leoshko, (ed.) Bodhgaya, the site of enlightenment, Bombay: Marg Publications, 1988: 46).
} 
upkeep and functioning of the temple, for digging a reservoir, cultivating rice-fields, supplying musical instruments, singing, dancing and so on. ${ }^{40}$

Two other missions followed this in the $13^{\text {th }}$ and $19^{\text {th }}$ centuries. Two monks accompanied the second mission, but they had to appeal to a local Indian ruler for money as they ran out of funds. These missions should be seen within the larger context of British military expansion as well as the religious policies of the rulers of Myanmar. In 1786 the island of Penang ceded to the East India Company and the same year the Company also acquired the Province of Wellesley in the Malay Peninsula. The Company continued to expand its sphere of political influence and in 1819 purchased the island of Singapore from the Sultan of Johore. It gained another important foothold in the region with the acquisition of Malacca in 1825 and, a year later, the British gained control over lower Burma.

Particularly relevant for this paper is the Burmese King Bodawphaya (1745-1819) who instituted reforms within the Buddhist monastic Sangha and also initiated a large-scale missionary policy in which he saw himself as a worthy successor of the Indian Mauryan ruler, Asoka. To ensure better control over the Sangha, he created a council of four superior monks to enforce greater discipline and this council was later enlarged to twelve. They had to meet regularly and its members were requested to submit unanimous decisions to the Mahadan-wun, the religious censor or minister of religious affairs. Two hundred and fifty-three books were brought from India and Sri Lanka and religious teachers congregated at Bodawphaya's court and took part in religious discussions. One result of these religious exchanges was the foundation of the Amarapura nikaya in Sri Lanka. ${ }^{41}$

In 1874, the Burmese King Mindon wrote to the Government of India and the Hindu mahant of Bodh Gaya, whose ancestors had been given ownership of the Buddhist temple by the Mughal ruler Shah Alam, for permission to carry out repairs of the temple

\footnotetext{
${ }^{40}$ Epigraphia Birmanica I, part II: 163-4.

41 Jacques P. Leider, 'Text, Lineage and Tradition in Burma: the struggle for norms and religious legitimacy under King Bodawphaya (1782-1819)', Paper presented at Exploring Theravada Studies: Intellectual Trends And The Future Of A Field Of Study, Asia Research Institute, National University of Singapore, 12-14 August 2004.
} 
and to build a monastery at the site for Buddhist monks. ${ }^{42}$ The Burmese delegation arrived in 1877 , but the restoration work carried out by them did not find favour with the archaeologists. In 1877, the Secretary of the Government of Bengal wrote to Rajendralal Mitra (1823/4-1891) stating that in the wake of conservation work done by the Burmese in 1305 and 1877, Mitra should visit Bodh Gaya "to inspect the work and the remains collected and to give advice as to their value and to their disposition and whether there are any that should go to the Asiatic Society; and generally to advise the Government in regard to the manner in which the operations of the Burmese excavators should be controlled."

Mitra was distinguished for his knowledge of Sanskrit, Persian, Urdu and Hindi, and edited several Sanskrit texts, including as The Sanskrit Buddhist Literature of Nepal, published in 1882. He was closely associated with the Asiatic Society of Bengal whose centenary history he wrote and which was published in 1885. Besides editing, translating and cataloguing manuscripts, his two pioneering works were The Antiquities of Orissa $(1875,1880)$ and Buddha Gaya, the Hermitage of Sakya Muni (1878).

Mitra's work on Bodh Gaya is based on the architecture of the site, but there are also sections on sculptures, on inscriptions dating from the early centuries of the Christian era to the $14^{\text {th }}$ century, and on historical chronology. He presents a detailed account of the village and the modern monastery, which was established early in the $17^{\text {th }}$ century, as well as the other structures surrounding the site. In his first report on the antiquities of Buddha Gaya, Cunningham had referred to a $10^{\text {th }}$ century inscription recording the dedication of a repository for aromatics and incense or a well-scented temple for the service of the Buddha on a slab of black stone. He had seen the inscribed slab attached to the gate of the monastery, where it served the purpose of a fulcrum for the gatehinge. Cunningham had castigated the owners of the record and stated, "Brahman malignancy has sadly mutilated this inscription by boring two large holes in the midst of the letters to serve as a socket for the lower pivot of one-half of the gate to work in." At Mitra's request, the late mahant presented it to the Asiatic Society of Bengal and, as Mitra argues, "these holes are the result, correctly speaking of indifference or want of

\footnotetext{
42 Alan Trevithick, 'British archaeologists, Hindu abbots, and Burmese Buddhists: The Mahabodhi Temple at Bodh Gaya, 1811-1877', Modern Asian Studies, 33 (1999): 648-51.
} 
respect for archaeology, and not of malignancy. ${ }^{, 43}$ Mitra was, however, critical of Burmese attempts at restoration.

The Burmese gentlemen were doubtless very pious and enthusiastic in the cause of their religion, but they were working on no systematic or traditional plan. They were ignorant of the true history of their faith, and perfectly innocent of all knowledge of architecture and the requirements of archaeology and history; and the mischief they have done by their misdirected zeal has been serious. ${ }^{44}$

On 15 January 1872, King Chulalongkorn of Siam arrived in Calcutta as a guest of the British who had almost reached the frontiers of the Siamese kingdom after the AngloBurmese war of 1826, which gave them control over lower Burma. In Calcutta, the king and his entourage visited the Asiatic Society of Bengal and the Indian Museum, which had several images from Java and other regions of Southeast Asia on display. During the king's forty-seven day visit, he travelled across the north to Delhi and Bombay, including a brief visit to Sarnath on 20-21 February. It is significant that on his return the Dhamekh stupa at Sarnath served as a prototype for at least two stupas at Bangkok, viz. Wat Somanass and Wat Kanmatuyarama. ${ }^{45}$

In 1898 the king of Siam staked his claim for the relics of the Buddha from Piprahwa in India. After obtaining the relics, he distributed portions among other claimants in Asia, such as Japan, Burma, Ceylon and Siberia. Those that remained in Siam were deposited in a gold and bronze shrine, which was installed in a stupa on the top of the Golden Mountain at Wat Sisaket in Bangkok. ${ }^{46}$

Thus clearly in the late $19^{\text {th }}$ century, the manipulation of religious markers for political advantage was gaining ground and conservation work carried out at Buddhist monuments provided yet another means to the government for exercising control over religious sites. From 1876 to 1884, the Bengal government spent two lakhs of rupees for

\footnotetext{
${ }^{43}$ Rajendralala Mitra, Buddha Gaya: The Hermitage of Sakya Muni, Calcutta: Bengal Secretariat Press (Published under Orders of the Government), 1878: 194-7.

${ }^{44}$ Rajendralala Mitra, Buddha Gaya: The Hermitage of Sakya Muni, Calcutta: Bengal Secretariat Press (Published under Orders of the Government), 1878: 66.

${ }^{45}$ S. Sahai, India in 1872: As Seen by the Siamese, Delhi: BR Publishing Corporation, 2002: 226. Journey to India in 1872 of King Chulalongkorn, Bangkok: River Books, 2000.

${ }^{46}$ S. Sahai, India in 1872: As Seen by the Siamese, Delhi: BR Publishing Corporation, 2002: 227.
} 
restoration of the Mahabodhi temple and as a result concluded that since the structure owed its present existence to the British, the Colonial State had a right to control it. ${ }^{47}$ This change in the nature of control of the shrine coincided with another mission, that of the religious reformer Anagarika Dharampala from Sri Lanka and the Theosophical Society to establish the primacy of Bodh Gaya in the Buddhist world and resulted in the installation of a custodian at Bodh Gaya.

The complexities of these developments can only be comprehended with reference to $19^{\text {th }}$ century Sri Lanka where monks of all the fraternities combined to actively oppose the work of Christian missionaries. Anagarika Dharampala was the Secretary of the Buddhist Theosophical Society, which the American, Colonel H.S. Olcott, and Madame Blavatsky had founded in 1880, and he not only reified Buddhist religious practices based on Orientalist writings of the period, but also endorsed the notion of a historical Buddha. In this mission to define Buddhist identity for himself and the Sinhalese nation, Bodh Gaya had a significant role to play as the centre for Buddhists from all parts of the world and it was the physical site of Buddha's Enlightenment that Dharampala sought to control. ${ }^{48}$ It is the intersection of Dharampala's religious zeal with Alexander Cunningham's quest for the historical Buddha that will form the theme of discussion in the next section.

\section{Construction of the Ancient Past}

One of the central issues in this section relates to the Mahabodhi temple and the historicity of the temple. The UNESCO charter describes it as the earliest construction in the subcontinent and hence of great historical value. How valid is this definition? There is no doubt that Bodh Gaya has been revered as a sacred site of pilgrimage from at least the $4^{\text {th }}-3^{\text {rd }}$ centuries B.C. onwards, but it is the Bodhi tree under which the Buddha is said to have attained enlightenment that has been the centre of piety. The VIII Rock Edict at Girnar in Gujarat records that ten years after his coronation, in around 259-8 B.C., the Mauryan ruler went to the sambodhi or visited the Bodhi tree as part of his travels for propagation of Dhamma. A platform to the east of the tree has

\footnotetext{
47 Indian Archaeology 1899-1905: 219. N. Lahiri, 'Bodh Gaya: an ancient Buddhist Shrine and its Modern History (1891-1904)', Timothy Insoll (ed.), Case Studies in Archaeology and World Religion, Oxford: BAR International Series 755, 1999: 33-43.

48 Torkel Brekke, Makers of Modern Indian Religion in the Late Nineteenth Century, Oxford: Oxford University Press, 2002: 114-5.
} 
been dated to the Mauryan period and was perhaps used for placing offerings to the tree. The temple, it is suggested, is secondary to the tree. ${ }^{49}$ As depicted on the railing at Bharhut, dated to the $2^{\text {nd }}-1^{\text {st }}$ centuries B.C. and recorded in an inscription from the site, the temple was an open structure enclosing the tree and the platform. "The present temple is largely a $19^{\text {th }}$ century British Archaeological Survey of India reconstruction based on what is generally believed to be an approximately fifth-century structure." $" 51$

In his search for sites associated with the Buddha, Alexander Cunningham relied on accounts by the Chinese pilgrims Faxian and Xuanzang who travelled to India in the $5^{\text {th }}$ and $7^{\text {th }}$ centuries respectively. Thus he argued that the extant brick temple at Bodh Gaya corresponded with the description given by Xuanzang and was certainly present at the time that the Chinese pilgrim visited the site, but Faxian makes no mention of it. Xuanzang, on the other hand, refers to a small vihara built by Asoka between 259 and 241 B.C. that predated the temple and refers to the construction of the temple by a Brahman "in compliance with the instructions of the god Mahadeva conveyed to him in a dream" and the placement of the image of the ascetic Buddha inside it. ${ }^{52}$ However, an inscription, which has been dated to A.D. 948 ascribes the building of the temple to the illustrious Amara Deva, one of the members of the court of King Vikramaditya "in compliance with the command of Buddha himself, conveyed to him in a vision."

From all the facts, which I have brought forward, such as the nonexistence of any temple in A.D. 400, the recorded erection of a large one by Amara Deva about A.D. 500 and the exact agreement in size as well as in material and ornamentation between the existing temple and that described by Hwen Thsang between A.D. 629 and 642, I feel satisfied that the present lofty temple is the identical one that was built by the celebrated Amara Sinha about A.D. 500. ${ }^{54}$

\footnotetext{
49 John C. Huntington, 'Sowing the Seeds of the Lotus: A Journey to the Great Pilgrimage Sites of Buddhism', Orientations, volume 16, 11, November 1985: 60.

${ }^{50}$ H. Lueders, Corpus Inscriptionum Indicarum II, part II, Bharhut Inscriptions, Ootacamund, 1963: 95.

51 John C. Huntington, 'Sowing the Seeds of the Lotus: A Journey to the Great Pilgrimage Sites of Buddhism', Orientations, volume 16, 11, November 1985: 61.

52 Archaeological Survey of India Annual Report volume I, 1871: 6.

${ }^{53}$ Archaeological Survey of India Annual Report volume I, 1871: 7.

${ }^{54}$ Archaeological Survey of India Annual Report volume I, 1871: 7-8.
} 
In spite of Cunningham's assertion scholars continue to debate the historicity of the present structure and the transformation of the tree shrine into the present temple, rectangular in plan and with a tower topped by an amalaka. Twenty stone models of the temple made between the early 13th and the late 15th centuries A.D. provide a crucial link in the fascinating record of the British discovery and restoration of the Mahabodhi temple. These stone models are widely dispersed from eastern India to Nepal, Tibet, Arakan and Myanmar and represent not just the Mahabodhi temple but the entire complex including the rectangular outer wall and a representation of the bodhi tree positioned on the west terrace. ${ }^{55}$ Francis Buchanan described the extension of the western terrace of the temple and the addition of twin buttresses when he visited Bodh Gaya in 1811 and 1812. Charles D'Oyly's drawing of the temple, made in 1824, clearly depicts this feature of the temple and the buttresses are also shown on Cunningham's plan of the temple. ${ }^{56}$ In the restoration of the 1880 s these buttresses were removed, as the tree had collapsed by then, and it was replanted from seedlings in its present position independent of the temple. Another casualty of the restorations of the several Burmese missions were the large numbers of memorials and subsidiary shrines earlier located in the precincts of the temple, as recounted in Xuanzang's description. ${ }^{57}$

Thus careful investigation of the multi-layered history of Bodh Gaya reveals not only its centrality in the wider networks of pilgrimage and travel, but more significantly the complex intersection of political interventions, well-meaning practices and religious identities. How are these to be contextualised within maritime history? In his work, Pearson emphasises non-economic exchanges across the Indian Ocean and the need to be amphibious, to move easily between land and sea. ${ }^{58} \mathrm{He}$ refers to the constant balancing in history between concerns of the land and those of the sea. It is this web of interconnections that makes research on the creation and maintenance of religious identities within the Indian Ocean world both fascinating and essential to an understanding of maritime networks. Or as Tagore presented so elegantly in his poems:

\footnotetext{
55 John Guy, 'The Mahabodhi Temple: Pilgrim Souvenirs of Buddhist India', The Burlington Magazine, CXXXIII, no. 1059, June 1991: 356-67.

${ }^{56}$ J.P. Losty, 'The Mahabodhi Temple before its Restoration' in G. Bhattacharya (ed.) Aksayanīvī: essays presented to Dr. Debala Mitra in admiration of her scholarly contributions, Delhi: Sri Satguru Publications, 1991.

57 John Guy, 'The Mahabodhi Temple: Pilgrim Souvenirs of Buddhist India', The Burlington Magazine, CXXXIII, no. 1059, June 1991: 364.

${ }^{58}$ M.N. Pearson, The Indian Ocean, London: Routledge 2003: 58.
} 
Standing by the shore, human beings saw the ocean in Front of them. One cannot imagine a bigger obstacle... The day dwarf-like human beings boldly proclaimed: "We will climb on the back of the ocean," the gods did not laugh. Instead, they whispered the mantra of victory in the ears of these rebels and waited. The back of the ocean is under control, the ocean's bottom is now being prospected. $^{59}$

\section{Bibliography}

Ahir, D.C. (1995) Asoka the Great, Delhi: B.R. Publishing.

Archaeological Survey of India Annual Reports.

Bapat, P.V. (ed.) (1956) 2500 Years of Buddhism (New Delhi: Publications Division.

Bayly, Susan (2000) 'French Anthropology and the Durkheimians in Colonial Indochina', Modern Asian Studies, 34(3): 581-622.

Blackburn, Anne M. (1993) 'Kinship and Buddhism: Ambedkar's Vision of a Moral Community', Journal of the International Association of Buddhist Studies, 16(1): $1-23$.

Bose, Sugata (2006) A Hundred Horizons, New Delhi: Permanent Black.

Brekke, Torkel (2002) Makers of Modern Indian Religion in the Late Nineteenth Century, Oxford: Oxford University Press.

Castro Gómez, Santiago (2007) 'The Missing Chapter of Empire: Post-modern Reorganization of Coloniality and post-Fordist Capitalism', Cultural Studies, 21(2-3): 428-448.

Chattopadyaya, B.D. (1993) "Historiography, History and Religious Centers" in Vishakha N. Desai and Darielle Mason (eds.) Gods, Guardians and Lovers (New York.

Cunningham, A. (1972) Mahabodhi or the Great Buddhist Temple under the Bodhi Tree at Buddha-Gaya, London: W.H. Allen and Company, 1892, reprint Varanasi: Indological Book House.

Cunningham, A. (1966) The Bhilsa Topes, Varanasi: Indological Book House.

Desai, D. (1989-90) "Social Dimensions of Art in Early India”, Proceedings of the Indian History Congress, Gorakhpur.

Edwards, Penny (2004) 'Relocating the interlocutor: Taw Sein Ko (1864-1930) and the itinerancy of knowledge in British Burma', South East Asia Research, 12 (3): 277-335.

\footnotetext{
${ }^{59}$ Rabindranath Tagore to Nirmalkumari Mahalanobis, July 17, 1927 in Rabindranath Tagore, Java Jatrir Patra (Letters of a Traveller to Java), Rabindra Rachnabali (Collected Works of Rabindranath Tagore), vol. 19, Calcutta: Vishwabharati, 1957: 462-3. Sugata Bose, A Hundred Horizons, New Delhi: Permanent Black, 2006: 249. Bose, 2006: 249.
} 
Edwards, Penny (2005) Taj Angkor: Enshrining L'Inde in le Cambodge' in Kathryn Robson and Jennifer Lee (eds) France and "Indochina": Cultural Representations, Oxford: Lexington Books.

Epigraphia Birmanica.

Epigraphia Indica.

Epigraphia Zeylanica.

Fitzgerald, Timothy (1999) 'Ambedkar, Buddhism and the Concept of Religion' in S. M. Michael, (ed.) Untouchable: Dalits in Modern India (Boulder: Lynne Rienner Publishers.

Guha-Thakurta, Tapati (2004) Monuments, Objects, Histories (New Delhi: Permanent Black.

Guy, John (1991) 'The Mahabodhi Temple: Pilgrim Souvenirs of Buddhist India', The Burlington Magazine, CXXXIII, no. 1059, June: 356-67.

Huntington, John C. (1985) 'Sowing the Seeds of the Lotus: A Journey to the Great Pilgrimage Sites of Buddhism’, Orientations, 16 (11): 46-61.

Lahiri, N. (1999) 'Bodh Gaya: an ancient Buddhist Shrine and its Modern History (1891-1904)', in Timothy Insoll (ed.) Case Studies in Archaeology and World Religion (Oxford: BAR International Series 755.

Leider, Jacques P. (2004) 'Text, Lineage and Tradition in Burma: the struggle for norms and religious legitimacy under King Bodawphaya (1782-1819)', Paper presented at Exploring Theravada Studies: Intellectual Trends And The Future Of A Field Of Study, Asia Research Institute, National University of Singapore, 12-14 August.

Leoshko, Janice (ed.) (1988) Bodhgaya, the site of enlightenment (Bombay: Marg Publications.

Leoshko, Janice (2003) Sacred Traces: British Explorations of Buddhism in South Asia, London: Ashgate.

Lueders, H. (1963) Corpus Inscriptionum Indicarum, Ootacamund.

Malandra, G.H. (1996) 'The Mandala at Ellora/ Ellora in the Mandala', Journal of the International Association of Buddhist Studies, 19(2): 181-208.

Mitra, D. (1980) Buddhist Monuments, Calcutta: Sahitya Samsad.

Mitra, Rajendralala (1878) Buddha Gaya: The Hermitage of Sakya Muni, Calcutta: Bengal Secretariat Press.

Mookerji, Radha Kumud (1912) Indian Shipping: A History of the Sea-borne Trade and Maritime Activity of the Indians from the Earliest Times (London: Longmans Green and Company.

Nandi, R.N. (1986) Social Roots of Religion in Ancient India (Calcutta, K.P. Bagchi and Company.

Nath, Vijay (2001) Puranas and Acculturation - A Historico-Anthropological Perspective, New Delhi: Munshiram Manoharlal. 
Nordholt, Henk Schulte (2004) De-colonising Indonesian historiography, Working Paper in Contemporary Asian Studies, no. 6 , Center for East and South-East Asian Studies, University of Lund, Sweden.

Omvedt, Gail (2003) Buddhism in India: Challenging Brahmanism and Caste, New Delhi: Sage Publications.

Pearson, M.N. (2003) The Indian Ocean, London: Routledge.

Prabha Ray, Himanshu (2003) The Archaeology of Seafaring in Ancient South Asia, Cambridge: Cambridge University Press.

Prabha Ray, Himanshu (2004) 'The Archaeology of Sacred Space: an Introduction', in Himanshu Prabha Ray and Carla Sinopoli (eds) Archaeology as History in Early South Asia, New Delhi: Indian Council for Historical Research and Aryan Books International.

Quilty, Mary Catherine (1998) Textual Empires: A Reading of Early British Histories of Southeast Asia, Clayton: Monash Asia Institute.

Reynolds, Craig J. (2006) Seditious Histories: Contesting Thai and Southeast Asian Pasts, Seattle and London: University of Washington Press.

Sahai, S. (2000) Journey to India in 1872 of King Chulalongkorn, Bangkok: River Books.

Sahai, S. (2002) India in 1872: As Seen by the Siamese, Delhi: BR Publishing Corporation.

Schopen, Gregory (1997) Bones, Stones and Buddhist Monks (Honolulu: University of Hawaii Press.

Sharma, R.S. (1987) Urban Decay in India (New Delhi, Munshiram Manoharlal.

Shaw, Julia (2001) 'Ancient Irrigation Works in the Sanchi Area: an archaeological and hydrological investigation', South Asian Studies, 17: 55-68.

Stephens, Harold (2005) 'Flying Visit to the Birthplace of the Lord Buddha,' Bangkok Post, 23 February.

Tagore, Rabindranath (1957) Java Jatrir Patra (Letters of a Traveller to Java) in Rabindra Rachnabali (Collected Works of Rabindranath Tagore) (Calcutta: Vishwabharati.

Tartakov, Gary M. (1996) 'New Paths to Sanchi' in V. Dehejia, (ed.) Unseen Presence: The Buddha and Sanchi, Bombay: Marg Publications.

Trevithick, Alan (1999) 'British archaeologists, Hindu abbots, and Burmese Buddhists: The Mahabodhi Temple at Bodh Gaya, 1811-1877', Modern Asian Studies 33:635-656. 